Companies are increasingly using written ethical codes to communicate their principles and practices; however, there have been few attempts to examine the complex language decisions the composers of such documents are likely to face in their attempt to "manage" the differing expectations of their readers. To reveal some of the rhetorical concerns that arise in constructing a code that is truly affiliative and inclusive of the readership and yet reflective of the goals of the corporation itself, this study focuses on the Dana Corporation's code. Using the standard linguistic technique of substitution to examine possible alternatives, especially the ways in which Dana refers to itself and its employees, brings to light some of the subtle rhetorical decisions that composers of ethical codes need to negotiate.

\title{
We the People? An Analysis of the Dana Corporation Policies Document
}

\author{
Priscilla S. Rogers \& John M. Swales \\ The University of Michigan
}

A mong U.S. companies there is what Cressey and Moore (1983) called for Business Ethics notes that "of those companies taking steps to institutionalize ethics, 93 percent have written codes of ethics in place, representing about a 5 to 10 percent rise over a 1979 study by the Ethics Resource Center and almost a 40 percent rise over a study for the Conference Board twenty years ago" (p. 86). ${ }^{1}$ The center's 1986 study also found written ethical codes to be the most popular device companies use to institutionalize their ethical principles. The popularity of corporate codes is further indicated by a 1987 Conference Board survey of 300 international senior executives in which 76 percent of the respondents reported having some kind of code (Berenbeim, 1987). ${ }^{2}$ Companies are increasingly using written ethical codes to communicate their principles and practices (Harris, 1978; Wakin, 1985).

Responses to the Conference Board's 1987 survey indicate that while corporate executives believe ethical codes have a limited effect in deterring intentional wrongdoers, codes play an important role in making employees aware that ethical, as well as economic and social, implications ought to be considered when making business decisions (Cavanagh, 1984). A code demonstrates a company's commitment to state its standards and to ask its workforce to incorporate these standards into their daily activities (Brenner \& Molander, 1977; Drake \& Drake, 1988). The Conference Board also found that companies have actually imposed penalties for violations outlined in their codes; for example, 61 percent of the companies whose codes include termination have actually imposed it over the last five years (Berenbeim, 1987). 
The fact that in recent years a growing number of $U$.S. companies have composed or revised written ethical codes may be attributed in part to the highly-publicized scandals which brought criticism, and in some cases warnings, from the general public, government agencies, and even business leaders themselves (Cressey \& Moore, 1983; Chewning, 1984; Gellerman, 1986; Wagel, 1987; Wakin, 1985). The budding ethical code movement is also associated with what Lodge (1977) called the "new ideology," which is summed up in the oft encountered phrase "corporate social responsibility" (Frederick, 1986; Sohn, 1982). ${ }^{3}$

The increasing significance of corporate ethical codes has, naturally enough, attracted the attention of scholars, observers, and consultants. The bulk of resulting literature suggests procedures for effective code design, promulgation, and enforcement (Austin, 1961; Berenbeim, 1987; Boulanger \& Wayland, 1985; Harris, 1978; Molander, 1987; Trevisan, 1986; Weller, 1988). ${ }^{4}$ A few studies review code content (Sanderson \& Varner, 1984). Among these, Cressey and Moore's (1983) thorough-going analysis of the policy areas and compliance procedures covered in over 100 codes from the Conference Board's John $\mathrm{H}$. Watson Library collection is especially useful. However, there seem to have been few attempts to examine the language of ethical codes (Fleming, 1987). ${ }^{5}$ This lack of attention to language choice is, we believe, unfortunate because it has tended to overlook the complex language decisions the composers of such documents are likely to face in their attempt to "manage" the different expectations of the various sectors in their intended readership.

To address language issues in corporate ethical codes we shall concentrate on the obvious crux of how corporations refer to themselves (and their constituencies) in the formal expression of their ethical philosophy and policies. As codes consist largely of propositions about preferred corporate behavior, the way the corporations refer to themselves as sentence subjects (we, XYZ Corporation, employees, XYZ people, etc.) and where and why those self-references vary, can be used to study differences in emphasis among corporate, sectoral, and individual affiliations and responsibilities.

We will center our discussion around Dana Corporation's code titled The Philosophy and Policies of Dana (henceforth PPD). We examine the PPD in some detail because we believe such analysis will reveal some little-addressed rhetorical concerns which arise in constructing a statement that is truly affiliative and inclusive of the primary readership (the internal audience of employees), and yet truly reflective of the various goals of the corporation itself. Analysis of PPD will include the standard linguistic technique of substitution in order to study the effect of alter- 
native rhetorical choices. By considering possible alternatives, especially in terms of how Dana refers to itself and its employees, we hope to demonstrate some of the subtle rhetorical decisions that composers of ethical codes need to negotiate.

\section{SIGNIFICANCE OF DANA AND THE DANA POLICIES DOCUMENT}

Dana Corporation is widely regarded as a successful company. An automotive and truck parts manufacturer based in Toledo, Ohio, Dana has through a series of tough restructuring decisions, become one of the most competitive suppliers of automotive and industrial parts in the world. Despite the vigor of its competitors, Dana earnings rose 15 percent in 1988 alone (The Wall Street Journal, 21 February 1989). "Dana," writes Abruzzese in the Journal of Commerce, "is considered one of the most progressive companies in the parts supplier industry" $(1987,7 \mathrm{~A})$.

At the same time, Dana is recognized as a top-flight employer in popular business literature, including The 100 Best Companies to Work for in America, and Dana's leaders earn kudos in the popular press for their "outstanding efforts in promoting a positive employee-relations philosophy" (Industry Week, 1986; see also Fortune, 1986; Business Week, 1987; The Wall Street Transcript, 1988). More significant here is the uniqueness of Dana's corporate ethical code and policy statement, The Philosophy and Policies of Dana (PPD), a uniqueness that prompted its selection from nearly 80 such documents. ${ }^{6}$

One of Dana's great strengths is said to lie in its consuming orientation towards people. Peters and Waterman characterize this orientation in their best-selling book, In Search of Excellence (1984):

The orientation is bond-deep and embedded in the language itself. At Delta, it's the "Family Feeling." At Hewlett-Packard, it's "the HP Way," and "Management by Wandering Around." At Dana, it's simply the constant use of the word "people" - in annual reports, in top executive speeches, in statements of policy (p. 239).

The emphasis on "people" is evident in Dana documents such as the flyer titled The Dana Style. All major sections in this document begin with two words: "Dana People." We read that "Dana People Serve the Shareholder," "Dana People Participate and Innovate," "Dana People Focus on Customers," and "Dana People Are Good Citizens." In a more subtle and intriguing way, this emphasis also reveals itself in the PPD, as this analysis will demonstrate. 
Another aspect of Dana which is directly relevant to those concerned with business communication and which recommends the PPD for study, is its emphasis on oracy. For instance, company folklore remembers the 1969 incident when former President Ren McPherson publicly dumped into the trash a sizable collection of detailed Dana policy manuals. As recently retired President Gerald B. Mitchell tells it, "We've worked to develop communication as an art. There is little, if anything, written down; it's all done orally" (Industry Week, 13 October 1986, p. 60). One important exception to the oral character of Dana communications is the PPD, the document initiated by President McPherson in 1969 that galvanized and inspired employees and brought Dana recognition as one of the nation's best companies (Levering, Moskowitz, \& Katz, 1985).

The PPD is also significant in that it is a signed document. The corporate codes we have accumulated suggest that this is rare. ${ }^{7}$ Generally there is either no indication of authorship at all (as is the case for the majority of such documents), or the code is merely signed with the name of the corporation (as are the Johnson \& Johnson "Our Credo," the Owens Corning Fiberglass "Winning Through Quality Performance," and the Trinova Corporation "Standards of Business Conduct"), presumably indicating both the code's official status and its implied consensual nature. Rather than avoiding the authorship issues altogether or supplanting a signature with the company name, PPD is signed by "The Policy Committee," a revelation that allows us to investigate particular rhetorical consequences that may follow from a declared authorship which is a subset of "all Dana employees" and yet empowered to speak on behalf of all.

A November 1989 visit with three members of the four-member Policy Committee, including Dana President and COO, Southwood ("Woody") Morcott, Executive Vice President, Borge Reimer, and Senior Vice President, Carl H. Hirsch, at Dana World Headquarters in Toledo, Ohio, allowed us to obtain reactions to our analysis of the PPD and confirmed many of our expectations. The emphasis on people came out strongly in the oft repeated commitment to the "promote-from-within policy" and in statements like "the PPD deals 80 percent with people." Nor was there anything to suggest that the long-standing rejection of paperwork had suffered any erosion: there were not many papers on the desks at Dana Headquarters; Policy Committee members almost never write memos; managers are expected to "communicate on their feet"; Dana does not believe in job descriptions, and so forth.

More striking was the obvious fervency with which these "keepers of the PPD" regarded the document. This fervency, they readily admitted, 
continues to inspire in them a kind of patriotism toward the valuable moral heritage articulated by the PPD's founding fathers, Gerald B. Mitchell and Ren McPherson. Referring to key tenets in the PPD, Borge Reimer asked rhetorically:

How could you argue against the idea that we should promote from within? How could you argue with the need to be a good citizen? What we have here is a belief system.

Elaborating, Reimer explained, "It's a little bit like when you pledge a commitment, as in church." Also with reference to the PPD, Woody Morcott described the enlarged copies of Dana principles hanging on the walls, the "pumped-up people," and the personally "uplifting" nature of his recent visit to a Dana rubber-products plant in Newborn, Tennessee. "They're living it better than we do!" he exclaimed.

Somewhat surprising, and more significant for this study, was discovering the pervasive power of the Policy Committee. While the Policy Committee, naturally enough, reports to a Board of Directors, it actually oversees Dana's World Operating Committee and is responsible for corporate strategies, people, philosophy, policy, and partnership relations globally (see appendix). The Policy Committee is, therefore, fundamentally concerned with providing leadership and vision. Central to this role is the PPD, which promulgates the Dana vision so that, as far as possible, it may become a way of life at Dana. The PPD is reviewed every year by the Policy Committee, the last significant changes occurring in 1987 to account for Dana's increasing globalization. That said, it also became clear to us in discussion that the Policy Committee believes the PPD represents enduring and successful company aspirations, which ultimately chart Dana's moral course and foster Dana's ethical standing.

\section{ANALYSIS OF THE PHILOSOPHY AND POLICIES OF DANA (PPD)}

The Philosophy and Policies of Dana (PPD) is a flyer that opens to the full-page, small-print, single-spaced document we analyzed. On the overleaf a five-sentence preface introduces the document as the philosophy that reflects Dana's basic thinking and concludes with the assurance that "The Policy Committee is responsible for our philosophy and our policies." We characterize the PPD as a hybrid code for it is both a credo or mission statement and an outline of fundamental principles and policies for Dana Corporation and Dana employees. ${ }^{8}$

The PPD itself, which is reproduced in Figure 1, consists of eight major sections titled "EARNINGS," "GROWTH," "PEOPLE," "PLANNING," 


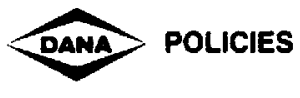

EARNINGS

The purpose of the Dana Corporation is to eam money for its shareholders and to increase the value of their investment. We believe the best way to do this is to earn an acceptable return by properly utilizing our assets and controling our cash.

GROWTH

We belteve in steady growth to protect our assets agarnst inflation. We will grow in our selected markets by implementing our market strategies.

PEOPLE

We are dedicated to the belief that our people are our most imoortant asset. Wherever possible. we encourage all Dana people within the entire world organization to become shareholders, or by some other means. own a part of their company.

We believe peopla resoond to recognition. treedom to participate. and the opportunity to develop.

We believe that people should be invoived in setting their own goals and judging their own performance. The people who know best how the jab should be done are the ones doing it.

We believe Dana people should accept only total quality in all tasks they perform.

We endorse productivity plans which allow pecple to share in the rewards of productivity gains.

We believe that all Dana people shouid identity with the company. This identity should carry on after they have left active employment.

We believe facilitues with people who have demonstrated a commument to Dana will be competitive and thus wartant our support.

We believe that wages and benetits are the concern and responsibility of managers. The Management Resource Program is a woridwide matter - it is a tool that should be used in the developmen of qualified Dana people. We encourage income protection, health programs. and education.

We believe that on-the-job traning is an eflective method of learning. A Dana manager must prove proficiency in at least one line of ou company's work mancinal services, etc. Additionally, these people must prove their abality as supervisors and be able to get work done through other people. We recognize the importance of gaining experience both intemationally and domestically.

We believe our people should move across product. discipline. ano organizational lines. These moves should not conftict with operating stficiency.

We believe in promoting from within. Dana people interested in other positions are encouraged to discuss job opportunitues with their supervisor

Managers are responsibie for the selection, education and training of all peopie.

All Dana people should have their job performance reviewed at least once a year by their supervisors.

We believe in providing programs to support the Oana Style. We We believe in providing programs to support the Oana Style. We people.

PLANNING

We believe on planning at all leveis.

The Policy Committee is responsible for developing the corporate strategic slan.

Each operating unit within its regional organization is responsible for a detalled five-year business plan. These business olans must support the coporate strategic plan and market strategies. These olans are reviewed annuaily.

Commitment is a key element of the Dana Management Style. This commitment and pertormance will be reviewed on a monthiy basis by commitment and pertormance will be reviewed on a monthly basis by basis during Mio-Year Rovews.

\section{OAGANIZATION}

We discourage conformity, uniformity and centratization.

We believe in a minimum number of management levels. Respons!bility should be pushed as far into the organization as possibie.

Organizationat structure must not contitet with dotng what is best for all of Dana.

We believe in an organizational structure that allows the individua maximum freedom to pertorm and participate. This will stimulate initiative, innovation, and the entrepreneunal spirit that is the cornerstone of our success.

We believe in smali, highly effective. support groups to service specialized needs of the Policy Committee and the world organization at large as requesied. We believe in task forces rather than permanent stat tunctions.

We da not believe in company-wide procedures. If an arganization requires procedures. It is the responsibility of the manager to create thern.

CUSTOMERS

Dana is a qiobal company focused on markets and customers. We compete globally by supplying praducts and services to meet the needs of our customers in our selected markets.

We are dedicated to the beliet that we have a responsibilty to be leaders in our selected markets.

We believe it is absolutely nocessary to anticipate our eustomers needs for products and services of the highest quality. Once a commitment is made to a customer, every effor must be made to fulfill that obligation.

It is highly desirable to outsource a portion of our production needs. Outsourcing increaseg our competitiveness and protects the stajility of employment for our people. It also protects our assets and assures Derformance to our customers.

Dana People throughout the organization are expected lo know our customers and their needs.

COMMUNICATION

We will communicate regulariy with shareholders. customers. Dana peopie, general oublic, and financiat communities.

Il is the job of all managers to keep Dana people intormed. Each manager must decide on the best method of communication We believe direct communication with all of our people eliminates the need for a third party invoivement. All managers shall penodically intorm their people about the pertormance and plans of their operation.

\section{CITIZENSHIP}

The Dana Corporation wil be a good cilizen worlowide. All Dana people are expected to do business in a proiessional and ethica manner with integrity.

Laws and regulations have become increasingly complex The laws of propnety always govern. The General Counsel and each Genera Manager can give guidance when in doubt about appropriate conduct It is expected that no one would willtully violate the law and subjec themselves to disciplinary action.

We encourage active participation of all of our people in community action.

We will support worthwhile community causes consistent with their importance to the good of Dana people in the community

The Folicy Committee Dana Corporatton

Approved by The Board of Directors Dana Corporation

\section{Figure 1}

\section{Reproduction of The Philosophy and Policies of Dana (PPD)}


"ORGANIZATION," "CUSTOMERS," "COMMUNICATION," and "CITIZENSHIP" respectively. Fully consistent with Dana's special attention to people, the section headed "PEOPLE" is by far the largest, containing more than twice the number of sentences found in any other section. It is also noteworthy that 18 of the 66 sentences in the document begin with the subject-verb duo "we believe," a fact that provides strong textual support for the view that the PPD is, whatever else it might be, quite literally a credo.

Of the 66 sentences in the PPD, 44 of them, fully two-thirds, have an opening subject that refers by various means to the entity Dana, that is, the company itself, its employees, or various sectors of those employees. Of these "employee-denoting" subjects, 33 (50 percent) are "we" subjects and 11 (17 percent) are other employee subjects such as "The people," "A Dana manager," "Dana people," and "The General Counsel." The 22 sentences that do not open with some kind of employee subject fulfill various special purposes, which we discuss later in this article. A breakdown of employee subjects is given in Table 1.

Table 1

Opening Employee Subjects

\begin{tabular}{lllll}
\hline Section & $\begin{array}{l}\text { A } \\
\text { \# of } \\
\text { Headings }\end{array}$ & $\begin{array}{l}\text { B } \\
\text { sentences }\end{array}$ & $\begin{array}{l}\text { B of } \\
\text { "employee- } \\
\text { denoting" } \\
\text { subjects }\end{array}$ & $\begin{array}{l}\text { B2 } \\
\text { subjects } \\
\text { other } \\
\text { "employee" } \\
\text { subjects }\end{array}$ \\
& & & & \\
\hline EARNINGS & 2 & 1 & 1 & 0 \\
GROWTH & 2 & 2 & 2 & 0 \\
PEOPLE & 24 & 20 & 16 & 4 \\
PLANNING & 7 & 3 & 1 & 2 \\
ORGANIZATION & 10 & 6 & 6 & 0 \\
CUSTOMERS & 8 & 4 & 3 & 1 \\
COMMUNICATION & 5 & 4 & 2 & 2 \\
CITIZENSHIP & 8 & 4 & 2 & 2 \\
TOTALS & $\mathbf{6 6}$ & $\mathbf{4 4}$ & $\mathbf{3 3}$ & $\mathbf{1 1}$ \\
\hline
\end{tabular}

\section{"We" Subjects}

The 33 sentences in the PPD that begin with the subject we suggest considerable writer discernment. Rather than presenting policies as directives in an "I'm-telling-you" fashion, the use of we sometimes serves to include readers who had little or nothing to do with creating those 
policies, and sometimes serves to affirm the credo-like function of the document. Sentences without we subjects also seem motivated. The following analysis posits possible reasons for these choices.

As we have already mentioned, the PPD is annotated at the bottom right with "The Policy Committee" and further endorsed with "Approved by The Board of Directors." However, it is not as though the Policy Committee is expressing its own views by the use of we in the PPD. Consider, for instance, the juxtaposition of the first two sentences in the "PLANNING" section:

1) We believe in planning at all levels.

2) The Policy Committee is responsible for developing the corporate strategic plan.

Citation 2) in fact is the single instance of "The Policy Committee" occurring in the document proper - the only other occurrences being the last sentence of the preface and the signature at the document's end. For this reason alone, "The Policy Committee" as a sentence subject clearly seems designed to distinguish 2) from 1) and the many other sentences beginning with we. If in fact 2) had used we, that use may have both subverted the authority of the Policy Committee as the creators of company policy and over-identified this we with the totality of the primary audience - an impression already created by the heavy use of $w e$ in the preceding section dealing with people. ${ }^{9}$ The following substitution illustrates these consequences:

2a) We are responsible for developing the corporate strategic plan.

On the other hand, several of the statements where we is the subject are decidedly managerial in tone:

3) We believe in promotion from within.

4) We endorse productivity plans which allow people to share in the rewards of productivity gains.

In such instances we represents the Policy Committee as speaking on behalf of all; however, using we rather than The Policy Committee seems a fitting attempt to identify managerial directives as employee responsibilities.

In her study of instructors' use of personal pronouns, Rounds (1987) labeled we forms of this kind as "authorial." Such usage, she suggests, is akin to an instructor announcing his lesson review with the words "We said last week that ...," or introducing the topic of his lecture with the phrase "Today we will cover...." Rounds' analysis suggests that in these instances, the instructor displaces the exclusive $I$ with the inclusive we 
and therefore, by implication, becomes "a cooperative partner acting in conjunction with the students" (p. 21). "By using a we that can be analyzed as an inclusive," Rounds maintains, "the teacher can identify himself as a member of the group consisting of students; they are linguistically subsumed in the teacher's monologic $I$ talk, becoming part of a we working cooperatively" (p.22). In a comparable way, it thus seems that the "authorial $w e$ " in the PPD may relegate the inherent status differences in superior-subordinate relationships at Dana to the subtext while concretizing an idealized environment in which all the participants, regardless of their relative power, are working together to achieve the company's goals.

The we references in the PPD also support the affirmatory credo-like function of the document as in the following example:

5)We believe in steady growth to protect our assets against inflation.

Here the we, like a pledge of faith, points to things hoped for, but perhaps not seen. Considering that the PPD is written by a high-level committee, alternatives to we in this case may be disingenuous, if not impossible to substantiate, as the following substitution illustrates:

5a) All of us at Dana believe in steady growth to protect our assets against inflation.

The substitution in item 5a) suggests interpretations that may be unmanageable, as illustrated by $5 b$ ) and $5 c$ ):

5b) All of us at Dana do actually believe in steady growth....

5c) All of us at Dana ought to believe in steady growth....

Item $5 \mathrm{~b}$ ) would be impossible to prove (and open to damaging falsification by counter-example) while item $5 \mathrm{c}$ ) reflects a world of pious and feeble optimism. Therefore, it seems likely that the original formation using we appears to have got it exactly right.

In discourse analysis it is often as important to understand what is not in the text (and why) as it is to investigate the actual textual phenomena (Brown \& Yule, 1983; Swales, forthcoming). In the Dana case, we note first the consistent avoidance of you. ${ }^{10}$ The "you-focused" codes in our sample are of the policies and procedures type and clearly "come from the top," leaving little doubt as to the subordinate position of the intended reader and reinforcing corporate hierarchy. They may have a distancing effect on the reader (Rounds, 1987). ${ }^{11}$ Compare citations 6) and 7) from IBM's "Business Conduct Guidelines" with citations 8) and 9) from the PPD: 
6) If you have any questions in interpreting or applying these guidelines. . it is your responsibil - $y$ to consult your manager or IBM legal counsel.

7) Everyone you do business with is entitled to fair and even-handed treatment. . . . You must treat all suppliers fairly.

8) We believe that people should be involved in setting their own goals and judging their own performance. ... We discourage conformity, uniformity, and centralization.

9) We believe it is absolutely necessary to anticipate our customers' needs for products and services of the highest quality. ... Dana People throughout the organization are expected to know our customers and their needs.

Among the codes in our collection, general mission statements or credos and hybrid codes such as the PPD tend to have a more consistent incidence of we than policy and procedure codes, perhaps because the closer one gets to "laying down the law," the more difficult it is to reinforce the transactional nature of communication and mutuality of human relationships. ${ }^{12}$ Yet, among all the codes, no matter their type (be they Johnson \& Johnson's "Our Credo," Booz, Allen, and Hamilton's "Statement of Professional Policies and Practices," or hybrid codes such as the "Chase Manhattan Corporation Code of Ethical Standards" and the PPD) the use of $w e$ and our, as Brown and Levinson suggest, indicates to readers that they "belong to some set of persons who share specific wants, including goals and values" (1978, p. 108). Rounds calls this "establish[ing] a group dynamic in terms of 'we-ness" " (p. 25).

We also notice in the PPD an avoidance of qualified subjects and of modal auxiliaries such as should, could, and must. These findings are not irrelevant since two of the identifying characteristics of legislative documents are their clarification of the scope of agentive subjects (who is included and excluded) and their heavy use of modals, especially shall (Bhatia, 1983). Legislative writing is intentionally specific as item 10) demonstrates:

10) All employees, except those on probation or otherwise specified in section $2 a$ below, shall receive....

The contrasting character of so many of the documents we examined suggests that corporate credos may be evolving away from elaborate quasi-legal codes of conduct and establishing themselves as a new genre (Miller, 1984). ${ }^{13}$ 


\section{Other "Employee" Subjects}

Eleven of the 44 employee-denoting sentence subjects in fact, do not use we, as shown in Table 1, Column B2. Six of these deal with identified subgroups such as managers. In such cases, of course, we is not a possible substitute. In the five other cases, the choice of an alternative to we is rhetorically interesting. Consider first the following three occurrences of (All) Dana people as subject:

11) All Dana people should have their job performance reviewed at least once a year by their supervisors.

12) Dana people throughout the organization are expected to know our customers and their needs.

13) All Dana people are expected to do business in a professional and ethical manner with integrity.

Upon reflection one discovers a potential problem with using we as an alternative subject in citation 11):

11a) We should all have our job performance reviewed at least once a year by our supervisors.

While 11a) is certainly affiliative and even-handed, it may raise "quis custodiet" types of questions in the minds of the readership, such as, "Who is the CEO's supervisor?" Of course, such queries could occur with the original All Dana People formulation, but we suggest that in this case plural first-personal-pronoun subjects are more likely to engender questions such as "Am I one of the "we' here?" or "Is she one of the 'we' in this regard?"

A comparable avoidance of such potentially awkward reader questions may have motivated 12). Presumably in any large organization there are some employees who do not need "to know" that organization's customersfor instance, maintenance staff, personnel in employee benefits, computersystems operators, and data processors. Here then, the we statement may more starkly create in the minds of such employees the rejoinder that 12) does not apply to them - and, of course, if 12) does not apply, perhaps the other statements do not apply. By using Dana people instead of we in citation 12), the writer avoids a "domino effect" where, by dismissing one tenet, the reader may disregard them all.

Reasons for the choice of All Dana people in item 13) seem harder to decipher. However, we can note that item 13) follows a statement about Dana being a good citizen worldwide. Perhaps, in this instance, if we had been used, it would have suggested a localized context; that is, a context 
particular to Dana's American operations as opposed to its global activity. Compare the following:

13a) We (Americans in the U.S.) are expected to do business in a....

13b) All Dana people (both in the States and in other countries) are expected to do business in a. ... ${ }^{14}$

While these individual explanations for the possible choice of (All) Dana people for 11), 12), and 13) hold some interest, it may be that what these sentences have in common most clearly accounts for their uniform subject. On second look we see that all are directives expressing reader obligation or duty. In 11) the directive is communicated with the modal auxiliary "should," whereas in 12) and 13) the word "expectation" prompts the same interpretation. ${ }^{15}$

Finally, two other subjects of note in this category are Dana and The Dana Corporation that opens the "CUSTOMERS" and "CITIZENSHIP" sections respectively:

14) Dana is a global company focused on markets and customers.

15) The Dana Corporation will be a good citizen worldwide.

We have no convincing rhetorical explanation for the shift away from $w e$ in these two cases, but we note that both have a copula-predicate structure. In item 15), at least, there may be some stylistic or grammatical preference for the singular subject over the plural we shown in 15a):

15a) We will be a good citizen worldwide.

In contrast, the use of Dana Corporation as part of the subject in the text's first sentence may be rhetorically motivated as the comparison below suggests:

16) The purpose of The Dana Corporation is to earn money for its shareholders and to increase the value of their investment.

16a) Our purpose is to earn money for our shareholders and to increase the value of their investment.

As others have indicated (Austin, 1961; Duncan, 1989), the topic of profit may be an awkward one for ethical statements. Consequently, it may surprise some observers that Dana and a number of corporations, including Dow Chemical Company, Honeywell Corporation, Squibb Corporation, and Varian Associates, opted to deal with profit at the outset. We know Dana Corporation encourages employees to become company owners through Dana's Stock Purchase Plan and provides a number of productivity plans by which employees share in the rewards of increased profitability. This may account somewhat for the fact that profit is given 
the highest priority in the PPD as may the fact that the authors of the PPD are directly responsible to the Board of Directors. At the same time, an opening statement like 16a) might run a serious risk of alienating the primary audience, especially if it were interpreted in personal terms:

16b) So. . .my purpose is to earn money for the shareholders. . . ?!

On the other hand, the use of the corporation name, especially in its official full form, operates to avoid such potential antagonisms.

\section{Nonemployee Subjects}

There remain 22 sentences that do not open with some kind of employee-denoting subject. Some are generalizations about the world, as in 17), and others are meta-comments about Dana, as in 18) and 19), none of which require direct employee association:

17) Laws and regulations have become increasingly complex.

18) The management research program is a worldwide matter.

19) Commitment is a key element of the Dana management style.

Yet others are consequential of "we believe" propositions, and therefore contain anaphoric elements as indicated below:

20) This identity should carry on after they have left active employment.

21) These moves should not conflict with operating effectively.

These sentences without employee subjects can therefore be understood as content-driven; that is, they are the seeming outcome of contextual necessity rather than rhetorical selection.

By contrast, the three sentences explaining the practice of company outsourcing in the "CUSTOMERS" section suggest deliberate writer choice by their context and their content:

22) It is highly desirable to outsource a portion of our production needs. Outsourcing increases our competitiveness and protects the stability of employment for our people. It also protects our assets and assures performance to our customers.

Sandwiched between sentences beginning with the subjects we and Dana people, this entry presents a noticeable and significant exception. The "It is highly desirable" format is the only occasion in the whole text where the authors opt for an impersonal, agentless, adjectival sentence opening. It looks anomalous, perhaps for good reason. Compare the following substitution:

22a) We believe in outsourcing a portion of our production needs. 
The fact that outsourcing can be a contentious issue which divides management and (organized) labor in contract and other negotiations is one that seems to recommend the impersonality of the "it is highly desirable" type. Moreover, it may go against the ethos of an all-employeeinclusive policies statement to announce with countervailing frankness that:

22b) It is Dana policy to outsource a portion of our production needs.

Given this context, therefore, we can see how the authors of the PPD have apparently made a careful rhetorical choice that steers the text between the Scylla of policy imposition and the Charybdis of falsely ascribing belief to a sector of the primary audience. 16

\section{CONCLUDING DISCUSSION}

We have presented a close but selective discourse analysis of an admired corporation's policy statement. The Philosophy and Policies of Dana (PPD) is an important document because Dana has an overall declared policy against paperwork and against regulative documents. Moreover, the PPD appears to be distinctive among Dana documents. It is, for example, considerably different from its companion piece, The Dana Style, in at least one important linguistic respect. The Dana Style refers constantly and consistently to "Dana people," whereas the PPD evinces, as we have seen, a clear preference for $w e$.

We have tried in this article to demonstrate how a textual analysis and follow-up interviews can, in general terms, reveal something of the complex rhetorical choices involved in articulating ethical principles and policies. More specifically, we have seen how a particular text appears to cope with its audience problem by using "we the people" in sufficient numbers of cases to allow instances of "we the Policy Committee," that is to say, "we the management," to pass, as it were, unobtrusively by. Further, we have tried to show that in cases where we might have remained problematic, the document provides alternative subjects such as "Dana," "Dana people," and "The Dana Corporation."

We believe that the approach presented here will have value in investigating the rhetorical choices made in other ethical codes and in enabling detailed comparisons to be made among them. One of the purposes of such studies is to furnish evidence as to how responsibility for the ethical well-being of a company is seen as being distributed. To what extent does ethical accountability rest with the corporate entity, its stockholders-owners, the board of directors, the CEO, the managers, 
the employees, or some other group such as the public at large, and how does one communicate that accountability in company codes or credos?

Our method has been to conduct a selectively detailed analysis of a key document, an analysis confirmed and enriched through interviews with its editors and signees. Of course, evidence provided by such textual analysis, even when informed by interviews, is incomplete. Even so, the advantages of this type of study are considerable. First, it presents a method of formulating preliminary hypotheses about both authoring decisions and reader reactions. Second, as we have tried to show, the black-and-white hard data in the actual texts can be used to reveal attitudes and orientations behind the mere expression of the content message. In this case, members of the Policy Committee confirmed our hunch that the discourse of this particular policy statement was highly constitutive of a world-view (Bizzell, 1987). Third, it seems to us that the kind of analysis we have presented here may have a potential role to play as input for those engaged in designing or redesigning corporate codes (Frederick, 1986). For instance, Dana Executive Vice President, Borge Reimer, commented that he would certainly re-read our study before the next PPD review. Fourth, this kind of rhetorical analysis may have a role to play in business ethics and business communication courses.

In studies of this kind it is common to attempt some kind of triangulation (Odell \& Goswami, 1985), which involves capturing and analyzing reader response. While the PPD is widely distributed - and may be posted in blown-up fashion in plants and offices - its value lies not in whether "it makes people feel good" but in the actions and behaviors it engenders. However, the members of the Policy Committee stated their belief that an outside research effort to examine reader response would offer little profitable outcome for the company. Moreover, Dana never employs outside consultants (except in very narrow technical areas). This belief is consistent, or course, with Dana's deliberate efforts in recent years to dramatically improve efficiency by streamlining activities, even at the basic nuts-and-bolts level, and by increasing employee involvement and commitment. The fact that any ethnographic hopes we may have had were politely denied is itself part of this affiliative but internal vision presented in the PPD. After all, we are not Dana people.

\section{NOTES}

${ }^{1}$ Addresses for the Center for Business Ethics and 15 other such organizations are provided by Fleming (1987). 
${ }^{2}$ Founded in 1916, the Conference Board is a business information and networking service with offices in New York, Ottawa, and Brussels (Berenbeim, 1987).

${ }^{3}$ Frederick describes "two great waves of literature about a corporation's interactions with society." The first wave, he suggests, focused on corporate social responsibility and began in the early $1950 \mathrm{~s}$ when scholars grappled to define the interface between business and society by exploring the notions of "responsibility" and "accountability." The second wave, Frederick suggests, focused on corporate social responsiveness and began in the 1970s when advocates urged companies to concentrate on acting responsibly by integrating social considerations into their strategic planning (1986, pp. 128, 130-131). It appears that the "budding ethical code movement" which Cressey and Moore describe is part of the second wave.

${ }^{4}$ Lewis (1985) provides a useful summary of research on business ethics in general.

${ }^{5}$ A tangentially-related study is Kallendorf and Kallendorf's (1989) application of select Aristotelian notions to the study of language as a tool for creating and disseminating corporate values. They also note "that comparatively little work has been done on ethics in corporate writing and speaking" (p. 54).

${ }^{6}$ We examined corporate ethical codes from 78 companies including automotive, chemical, consulting, consumer products, financial services, manufacturing, pharmaceutical, and service firms both large and small. These codes are as diverse in presentation as Pillsbury's five-by-seven embossed card titled "The Pillsbury Company Mission and Values," and IBM's 42-page booklet titled "Business Conduct Guidelines."

${ }^{7}$ Other signed codes include: a) Hallmark Cards' 'Standards of Business Conduct: Community and Business Relationships, ${ }^{n}$ signed by three vice presidents under the close "APPROVED BY"; b) Heller Financial's "Employee Guidelines" from the "Corporate Human Resources Department"; c) Sears, Roebuck, \& Company's "Standards of Ethical Business Conduct for Corporate Personnel," signed by a single individual, namely E.A. Brennan; and, similarly unusual, Whirlpool Corporation's "Ethics as a Practical Matter," signed by Chairman of the Board, David R. Whitwam. Frequently codes are prefaced with a signed letter of transmittal from the company Chairperson, CEO, President, Senior Vice President, or, in a few instances, from the company itself. As a note of interest, these letters usually include three basic parts: 1) a paragraph stressing the significance of the code, often recounting the importance of upholding the company's outstanding reputation; 2) an introduction to the code itself, sometimes associating the code with the corporate philosophy, and 3) a call for reader action that might be as general as asking readers to conduct themselves according to the code's standards, or as specific as requiring readers to sign and promptly return an acknowledgement form.

${ }^{8}$ Despite their diversity, the codes in our collection fall into three broad categories: 1) General mission statements or credos are typified by "The Best Foods Baking Group Guide to Excellence," Whirlpool Corporation's "Ethics as a Practical Matter," Security Pacific Corporation's "Fulfilling Six Commitments," and the now famous Johnson \& Johnson "Our Credo." 2) Specific descriptions of corporate policies and procedures include documents such as 
General Motors' "Guidelines for Employe[e] Conduct," and Booz, Allen, and Hamilton's "Statement of Professional Policies and Practices." 3) Hybrid codes include both a mission statement and a description of corporate principles and policies. They are well represented by Caterpillar's "A Code of Worldwide Business Conduct and Operating Principles," and General Electric's "Statement of Ethics and Standards of Conduct: A Commitment to Integrity." All the codes in our sample share the two basic features identified in 1987 by the Conference Board: 1) they are carefully articulated statements of ethical principles that are rooted in the founder's philosophy, the company's business objectives, or the company's organizational history and traditions, and 2) they explicitly state that the company and its employees are to follow these principles.

${ }^{9}$ In the textual analysis prior to our Dana visit, we were struck by the order of the statements in the Planning Section. It seems to us that after the opening statement ("We believe in planning at all levels.") it might be more consistent with the affiliative character of the document to present the planning decisions in a bottom-up manner, mentioning regional decisions before corporate decisions. Having met with members of the Policy Committee, we now realize that the top-down order in this section (beginning with "The Policy Committee is responsible for developing the corporate strategic plan") accurately reflects Dana's vision. To paraphrase Executive Vice President Borge Reimer, "At Dana, style may change, but vision and belief can only come from the top, from the leader" (1989).

10 The codes in our sample can be placed into three broad categories according to their pronoun use: a) "no-pronoun" codes, b) "you-focused" codes, and c) "we-focused" codes. "No-pronoun" codes contain pronouns only in introductory and / or concluding sections or contain no pronouns at all. These codes rely on nouns, particularly the company name and the word "employee" and tend to read like legal documents. Consequently, they are dramatically different than "we-focused" codes like the PPD. In our experience, the first-person pronoun $I$ is almost never used in corporate ethical codes. An exceptional case is Whirlpool Corporation's code titled Ethics as a Practical Matter which is presented, in highly unorthodox form, as a personal message from David R. Whitwam, Chairman of the Board. "Pledge sheets," which are sometimes attached to codes, regularly include $I$ as in: $I$ certify that $I$ have received and read the [National City Corporation] Ethics Policy, dated September 1, 1987, and that $I$ understand and will comply with the policies stated therein."

${ }^{11}$ Our examination of "you-focused" codes suggests they are more often negative in tone including words such as "no," "not," and "avoid."

${ }^{12}$ Policy and procedure codes that do employ we and our frequently do so sporadically; for example, in "General Dynamics Standards of Business Ethics and Conduct," half of the major section headings include our, as in "OUR COMMITMENTS" and "OUR STANDARDS," yet some minor sections under these headings such as "Antitrust" and "Expense Reports" include no we or our pronouns. Analysis of such choices may also yield useful information.

${ }^{13}$ Todorov discusses genre evolution: "A new genre is always the transformation of one or several old genres: by inversion, by displacement, by combina- 
tion" (1976, p. 161). Miller (1984) comments on the problems attending the birth of the environmental impact statement.

${ }^{14}$ Discussion with the Policy Committee revealed the fact that Dana is a highly decentralized operation with many affiliates. While the PPD is made available to management on a worldwide basis, consequent action is left to the judgment of the management at each location. Perhaps for this reason it was not clear from our discussion with the Policy Committee if the PPD had been translated.

${ }^{15}$ In our collection we found only three codes in addition to the PPD that employ the "XYZ people" form in the actual code: "AT\&T people," "IBM people," and "MNC (Michigan National Corporation) people." Almost half of these instances include a modal auxiliary or some form of the word "expect." Consider the following examples: 1) $M N C$ people should not purchase, nor seek to purchase, any bank asset not offered publicly for purchase... 2) $M N C$ people must be aware that personal financial affairs reflect to the public the character of the organization. 3)... the expectation and assumption [is] that all activity undertaken by $A T \& T$ people. . .conforms to the highest standards of integrity.

${ }^{16}$ When we asked the members of the Policy Committee why a document like the PPD referred to outsourcing at all, we were told that outsourcing was necessary "to protect the heart of the product line" and that "cash flow is everything." After posing such questions, we found that members of the Committee wanted to discuss the document "conceptually" rather than to detail its stylistic or rhetorical features. The only exception to this response was the volunteered comment that at one time they ran the PPD through the Fog Index in an attempt to simplify the language.

\section{REFERENCES}

Abruzzese, L. (1987). Protectionism no panacea: Truck equipment maker offers alternatives. Journal of Commerce, 371, 7A.

Austin, R.W. (1961, September-October). Code of conduct for executives. Harvard Business Review, p. 53.

Bhatia, V. K. (1983). An applied discourse analysis on English legislative writing. Birmingham, England: The University of Aston, LSU.

Bizzell, P. (1987, July). Some uses of the concept of "discourse community." Paper presented at the Penn State Conference on Rhetoric and Composition.

Beauchamp, T., \& Bowie, N. (1983). Ethical theory and business (2nd ed.). Englewood Cliffs, NJ: Prentice-Hall.

Berenbeim, R. E. (1987). Corporate ethics. New York: Conference Board.

Berry, B. H. (1987, March). Dana's Project 90 aims at manufacturing excellence. Iron Age, 230, 37-39.

Boulanger, R., \& Wayland, D. (1985). Ethical management: A growing corporate responsibility. CA Magazine, 118(4), 50-53.

Brenner, S. N., \& Molander, E. A. (1977). Is the ethics of business changing? Harvard Business Review, pp. 55, 57-71. 
Brown, P., \& Levinson, S. C. (1987). Politeness: Some universals in language usage. Cambridge: Cambridge University Press.

Brown, G., \& Yule, G. (1983). Discourse analysis. Cambridge: Cambridge University Press.

The CEO 1000. (1987, October 23). Business Week, p. 164.

Cavanagh, G. F. (1984). American business values (2nd ed.). Englewood Cliffs, NJ: Prentice-Hall.

Center for Business Ethics (1986). Are corporations institutionalizing ethics? Journal of Business Ethics, 5 (2), 85-91.

Chewning, R. C. (1984). Business ethics in a changing culture. Reston, VA: Prentice-Hall.

Cressey, D. R., \& Moore, C. A. (1983). Managerial values and corporate codes of ethics. California Management Review, 25, 53.

Dana Corporation. (1989, February 21). Firm says 4th-period net doubled to $\$ 43.7$ million. [Business Brief]. The Wall Street Journal, p. B2(E).

Dana Corporation. (1989). File of pamphlets and news clippings. Available at Career Resource Center, KBAL, School of Business Administration, University of Michigan, Ann Arbor, MI 48109-1234.

Drake, B. H., \& Drake, E. (1988). Ethical and legal aspects of managing corporate cultures. California Management Review, 30 (2), 107-123.

Duncan, W. J. (1989). Great ideas in management. San Francisco: Jossey-Bass.

Engle, P. C., Moske, B. S., Goldstein, M. L., Braham, J., \& Modic, S. (1986, October 13). IW's 10th annual excellence in management awards. Industry Week, 231, 51-59.

Falsey, T. A. (1989). Corporate philosophies and mission statements: A survey and guide for corporate communicators and management. New York: Quorum.

Fleming, J. E. (1987). A survey and critique of business ethics research, 1986. In W. C. Frederick (Ed.), Research in corporate social performance and policy: Vol 9, Empirical studies of business ethics and values (pp. 1-23). Greenwich, CT: JAI Press.

Frederick, W. C. (1986). Toward CSR: Why ethical analysis is indispensable and unavoidable in corporate affairs. California Management Review, 126-141.

Gellerman, S. W. (1986). Why good managers make bad ethical choices. Harvard Business Review, pp. 85-90.

Gorlin, R. A. (1986). Codes of professional responsibility. Washington, DC: Bureau of National Affairs.

Harris, C. E. (1978). Structuring a workable business code of ethics. University of Florida Law Review, 30, 310.

Kallendorf, C., \& Kallendorf, C. (1989). Aristotle and the ethics of business communication. Journal of Business and Technical Communication, 3(1), $55-69$.

Levering, R., Moskowitz, M., \& Katz, M. (Eds.) (1985). Dana Corporation. In The 100 best companies to work for in america (pp. 62-66). New York: New American Library. 
Lewis, P. V. (1985). Defining "business ethics": Like nailing Jello to a wall. Journal of Business Ethics, 4(5), 377-383.

Louis, A. M. (1986, April 14). The US business hall of fame. Fortune, 113, pp. 104-110.

Lodge, C. L. (1977). Managerial implications of ideological change. In C. C. Walton (Ed.), The ethics of corporate conduct (pp. 79-105). Englewood Cliffs, NJ: Prentice-Hall.

Miller, C. R. (1984). Genre as social action. Quarterly Journal of Speech, 70, 151-167.

Molander, E. A. (1987). A paradigm for design, promulgation, and enforcement of ethical codes. Journal of Business Ethics, 6(8), 519-631.

Odell, L., \& Goswami, D. (Eds.) (1985). Writing in nonacademic settings. New York: The Guilford Press.

Peters, T. J., \& Waterman, R. H. (1984). In search of excellence: Lessons from America's best-run companies. New York: Warner Books.

Rogers, P. S., \& Swales, J. M. (1989, November 16). [Southwood "Woody" Morcott, President \& COO, Dana Corporation. Dana World Headquarters, Toledo, OH.] Unpublished interview.

Rogers, P. S., \& Swales, J. M. (1989, November 16). [Carl H. Hirsch, Senior Vice President, \& Borge Reimer, Executive Vice President, Dana Corporation. Dana World Headquarters, Tbledo, OH.] Unpublished interview.

Rounds, P. (1987). Multifunctional personal pronoun use in an educational setting. English For Specific Purposes, 6(1), 13-29.

Sanderson, G. R., \& Varner, I. I. (1984). What's wrong with corporate codes of conduct? Management Accounting, 66 (1), 28-31, 35.

Sohn, H. F. (1982). Prevailing rationales in the corporate social responsibility debate. Journal of Ethics, 1, 139-144.

Swales, J. M. (forthcoming). English in Academic and Research Settings: Genre Analysis and Its Applications. Cambridge: Cambridge University Press.

TWST names award winners: Auto parts, original equipment (1988, July 11). The Wall Street Transcript.

Todorov, T. (1976). The origin of genres. New Literary History, 8, 159-170.

Trevisan, R. E. (1986). Developing a statement of ethics: A case study. Journal of Purchasing \& Materials Management, 22 (3), 8-14.

Wagel, W. H. (1987). A new focus on business ethics at General Dynamics. Personnel, 64 (8), 4-8.

Wakin, E. (1985). Business, ethics, and the bottom line. Today's Office, 19 (9), 22-30.

Weller, S. (1988). The effectiveness of corporate codes of ethics. Journal of Business Ethics, 7(5), 389-395.

Wilkins, A. L. (1989). Developing corporate character: How to successfully change an organization without destroying it. San Francisco: JosseyBass. 


\section{APPENDIX}

\section{Dana Corporation Organizational Chart}

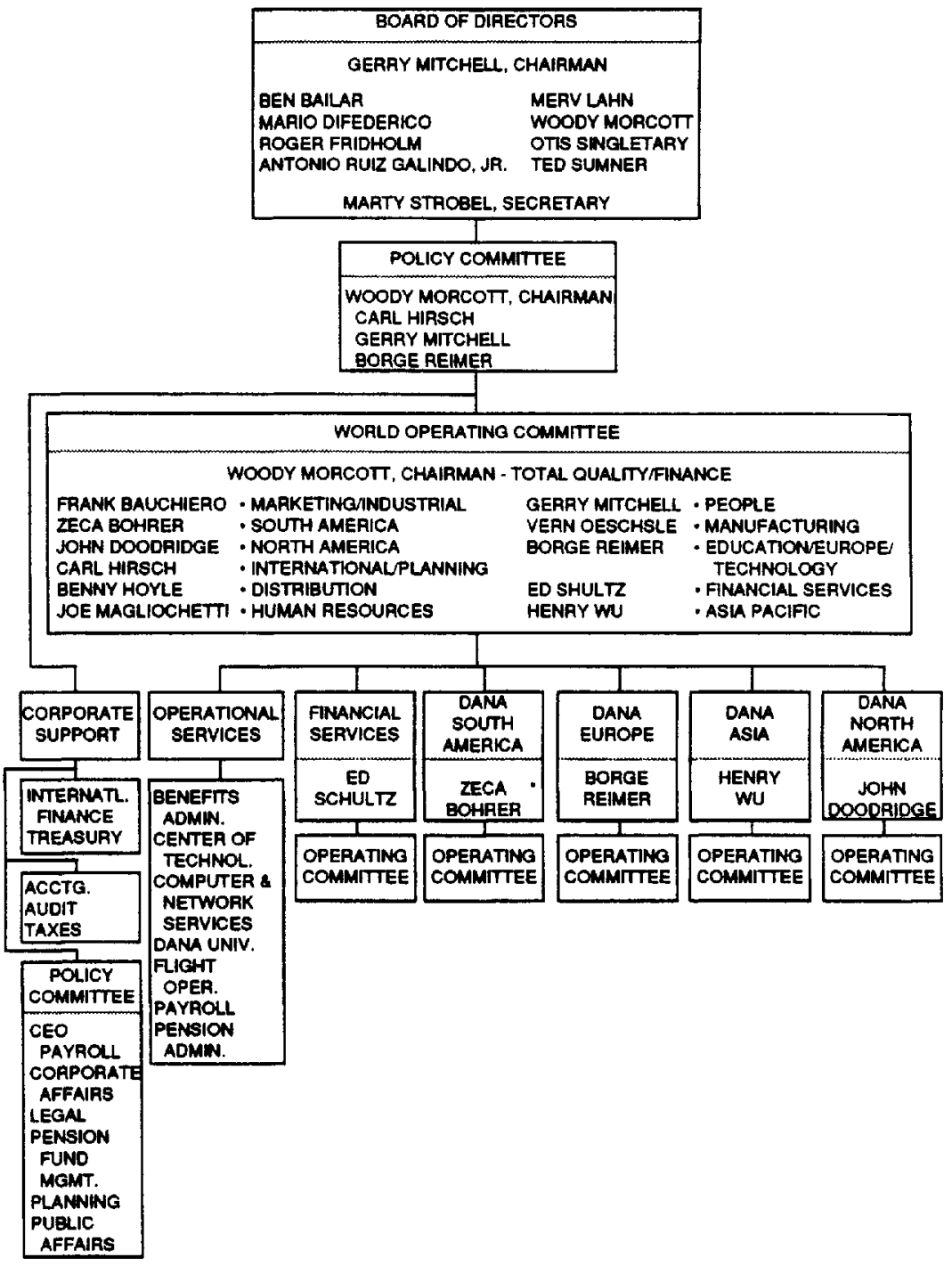

